\title{
Social-Cultural Ecosystem Services of Sea Trout Recreational Fishing in Norway
}

\author{
Yajie Liu'1,2*, Jennifer L. Bailey ${ }^{3}$ and Jan G. Davidsen ${ }^{4}$ \\ ${ }^{1}$ Norwegian College of Fishery Science, Faculty of Biosciences, Fisheries and Economics, UiT The Arctic University of \\ Norway, Tromsø, Norway, ${ }^{2}$ Department of Economics, Faculty of Economics and Management, Norwegian University \\ of Science and Technology, Trondheim, Norway, ${ }^{3}$ Department of Sociology and Political Science, Faculty of Social \\ and Educational Sciences, Norwegian University of Science and Technology, Trondheim, Norway, ${ }^{4}$ NTNU University \\ Museum, Department of Natural History, Trondheim, Norway
}

This paper explores the ecosystem services provided by anadromous brown trout (often termed sea trout) populations in Norway. Sea trout is an important species in both freshwater and marine ecosystems and provides important demand-driven ecological provisioning and socio-cultural services. While the sea trout once provided an important provisioning service through a professional fishery and subsistence fishing, fishing for sea trout in the near shore coastal areas and in rivers is today a very popular and accessible recreational activity and generates primarily socio-cultural services. The recreational fishery contributes to local cultural heritage, its folkways and lore, to the development and transfer of local ecological knowledge and fishing experience to the young and to human well-being. As a salmonid species, the sea trout is sensitive to negative environmental conditions in both freshwater and marine coastal areas and is in general decline. A recent decision to expand production of farmed salmon may increase pressure on stocks. Good management of recreational fishing is accordingly important for the species to thrive, but knowledge of what fishers value with respect to fishing sea trout and what management measures they will accept is limited. Researchers sought to capture information about non-extractive direct use value (non-monetary) of the sea trout recreational fishery using questionnaire surveys targeting Norwegian anglers around the country. Results indicate that the most important ecosystem services delivered by recreational sea trout fisheries are social-cultural ecosystem services at the level of individual fishers; fishing sea trout most likely also has important social functions. Fishers are prepared to accept stricter management measures that reduce catches and allow fishing to continue but they oppose paying higher fees.

Keywords: cultural value, ecosystem services, educational value, recreational value, sea trout, social-ecological system, stakeholders, trade-offs

\section{INTRODUCTION}

Recreational fishing in salt and fresh water environment has been a legal right for local residents and a millennia-long tradition in Norway (Norges Offentlige Utredninger [NOU], 1999). Generally speaking, a high percentage of Norwegians participate in recreational fishing, and much of this catch has traditionally been consumed (Hyder et al., 2018). Anadromous species such as Atlantic salmon (Salmo salar L.), brown trout (Salmo trutta L.) and Arctic char 
(Salvelinus alpinus L.) have been especially important. Due to changes in the environment and fish populations, stocks of these fish have declined and fishing such species in the rivers and streams has gradually become a high-value recreational activity in Norway and worldwide (Hyder et al., 2018). The official policy to significantly expand Atlantic salmon aquaculture in Norway, however, may put these resources at increased risk (Liu et al., 2011; Anon, 2018). It is accordingly important to better understand what ecosystem services are being put at risk, how valuable they are and how this knowledge could contribute to better management.

The paper focuses on anadromous brown trout (hereafter termed sea trout) fishing in Norwegian rivers and near-shore coastal areas. The sea trout plays an important role in aquatic systems (Butler et al., 2009), and it also provides important social-cultural services for human communities. This paper uses an ecosystem services approach to examine more closely the ecosystem services that these resources generate, especially those associated with fishing as a recreational activity. The focus is especially on the social-cultural ecosystem services of sea trout fishing that are less frequently covered in the literature (Blicharska and Rönnbäck, 2018). It looks at the non-extractive direct use value (non-monetary) of sea trout at both the angler level (e.g., recreational fishing) and for their communities at large, which also tends to be neglected.

The value of some services can be measured in monetary terms, such as provisioning services, while others are difficult to measure due to complex biological functions and processes and lack of market, such as for some social-cultural services. Sea trout and other salmonids were in the past a valuable food source; today commercial fishing of sea tout has significantly declined and subsistence fishing has largely disappeared. This stock is better characterized as an important ingredient of the very popular recreational fishing for which Norway is well known. Previous studies have attempted to measure the monetary value of recreational salmonid fishing at the branch/national level from the data collected at river levels, and catches of both Atlantic salmon and sea trout in the coast and rivers are collected annually. However, many social-cultural services of sea trout and other salmonids are more difficult to identify, less amenable to valuation and less well studied.

Using structured questionnaires distributed to Norwegian anglers, this paper explores the ecosystem services related to sea trout recreational fishing and discusses their possible values from the perspective of Norwegian fishers and from the perspective of the broader community. Survey results reveal that social-cultural ecosystem services of recreational fishing are far more important and diverse than are provisioning services.

\section{SALMONID FISHING IN NORWAY}

Salmonid fishing including Atlantic salmon, sea trout and Arctic char in rivers and streams has had a range of significant social, cultural and economic values for Norwegians, especially coastal communities, for thousands of years (see Figure 1). Protecting salmonids including sea trout populations has long been an important political goal in Norway - and it is also Norwegian law. Norway officially manages anadromous species with the objectives of both conserving the stocks and producing a harvestable surplus [Salmonid and freshwater fishing law (Anon, 1995)]. In the past, that surplus was intended for harvest by commercial, subsistence and recreational fisheries. In recent years, however, commercial catches of salmonids in the sea have gradually declined due to the driftnet ban in 1989, replaced by recreational, artisanal and subsistence fishing (Baklien and Steinset, 2012). Recreational fishing along the coast (including in fjords) is free of charge while a fishing license is required for fishing in rivers. It is the owners of the riverbanks who control the right to fish in Norwegian rivers and for some, selling fishing licenses and services connected with fishing tourism, provides an important source of income. Government policy in the past encouraged commodification of both fishing and hunting rights held by rural landowners as a means by which to keep rural areas economically viable (Stensland, 2013). In recent decades, increasingly strict regulations have been introduced as salmonid stocks have become more fragile. Today in most watercourses, there are strict regulations on bag limit, i.e., how many fish can be kept per day and/or per season for each river or a watercourse.

Much previous work on salmonid fishing in Norway has focused on Atlantic salmon. This is because Atlantic salmon is the most highly valued of the anadromous species traditionally exploited in commercial, subsistence and recreational fisheries. For example, in 2017, 375 tons of Atlantic salmon were removed from rivers, compared to 45 tons of both sea trout and Arctic char; 290 tons of Atlantic salmon were removed from marine waters that year, compared to 42 tons of sea trout (Figure 2) (SSB, 2018). Catch figures show that roughly twice and a half as many Atlantic salmon were caught and released than were sea trout and Arctic char (about 26,000 Atlantic salmon vs. just over11,000 sea trout and Arctic char) (SSB, 2018). However, it is also the case that these are in many ways similar species and fisheries. Fishers often take various salmonids, although they also often have preferences as this study will show. While the intent here is to focus as much as possible on the sea trout, it is frequently difficult to separate this species from the other salmonids and from marine species in terms of recreational fishing behavior and attitudes.

The community of recreational fishers is large and diverse in Norway. The Norwegian Association of Hunters and Anglers (NJFF) reports that $50 \%$ of the total population of Norway (estimated at 5.3 million) goes fishing at least once a year and that $70 \%$ of children between the ages of 11 and 16 also do so. For all age categories, approximately $65 \%$ of those fishing are male. These figures, however, include a wide variety of recreational fishers, ranging from those who fish in seawater for cod and in freshwater for salmonids, and presumably, varying levels of dedication to the sport. About $5-10 \%$ NJFF members fish for anadromous species (including Atlantic salmon, sea trout and Arctic char), usually using a rod and bait (stangfiske) or a hand line; the majority fish in salt water (fjords) rather in rivers (NJFF, 2018). Approximately 100 thousand Norwegians are estimated to participate in fishing for salmonids each year (NEA, 2018). 

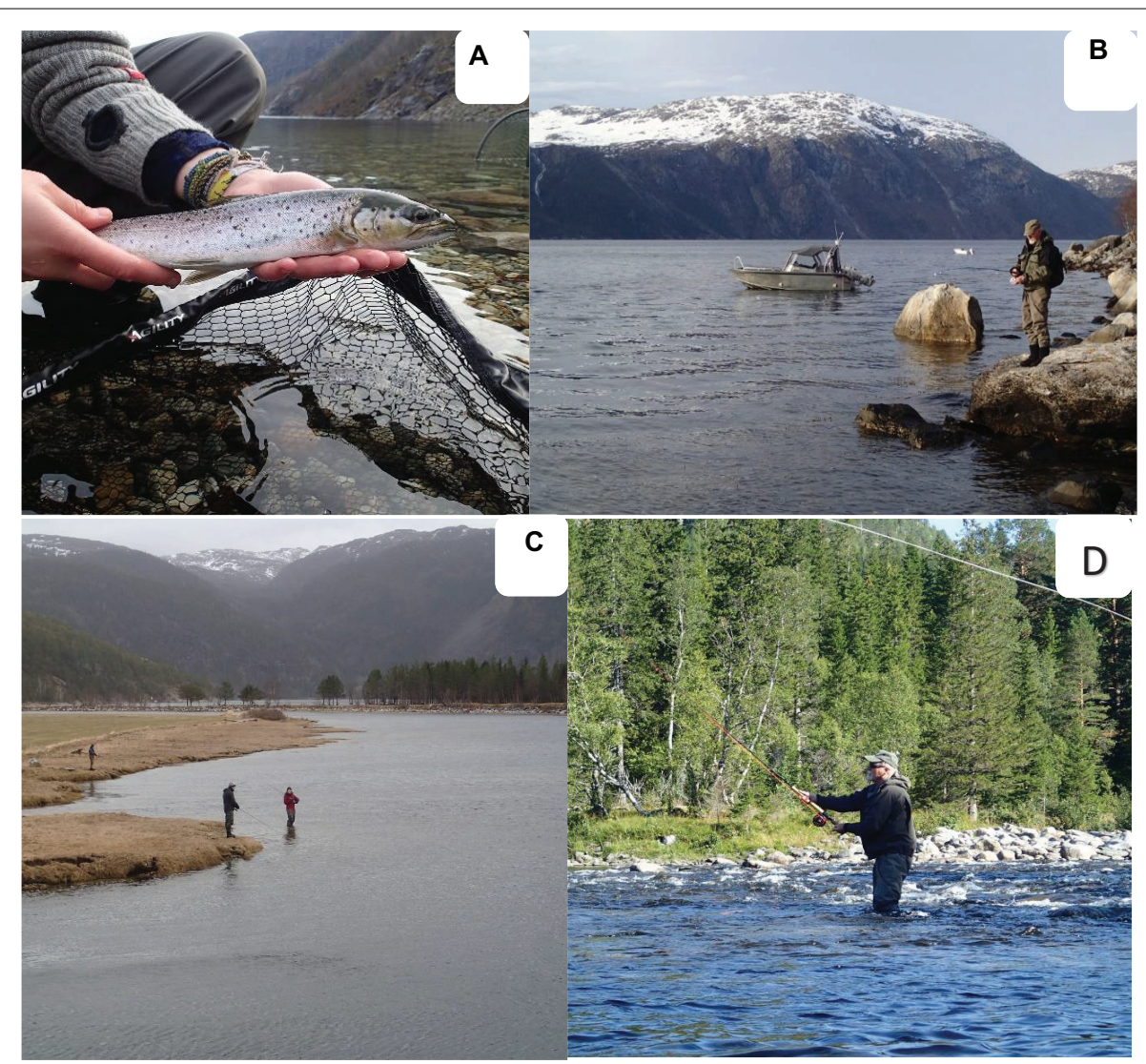

FIGURE 1 | Sea trout fishing in Norwegian rivers. (A) Sea trout caught for tagging; (B) Fishing in the Urvolfd estuary of Tosenfjord; (C,D) Fishing in Åelva River, in Nordland country. Credit: Jan G. Davidsen.

Aas and Kaltenborn's (1995) review of the literature suggests that Norwegian anglers are on the whole similar to those found elsewhere (e.g., Ferter et al., 2013). The Norwegian Environmental Agency (NEA, 2018) describes Norwegian fishers as enjoying nature and fishing as an important leisure activity.

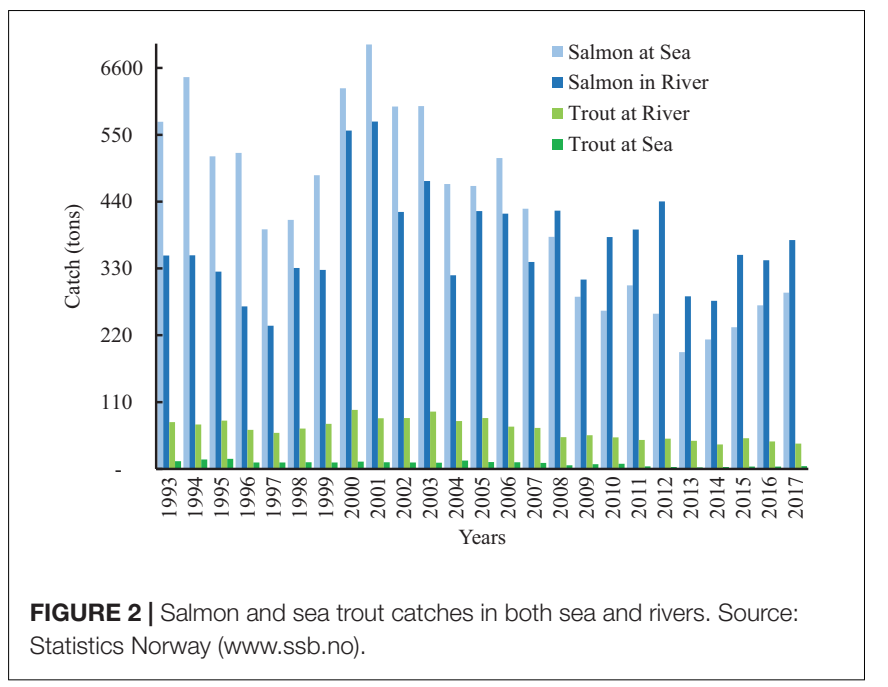

The NJFF highlights the excitement of fishing and landing the fish as motivations for Norwegian fishers (Spenning og høsting går hånd $i$ hånd som motiv for de fleste fiskerne). Others describe the importance of recreational fishing in Norway in terms of social motivations such as preserving traditions and culture (Norges Offentlige Utredninger [NOU], 2013; NMA, 2018). Some studies (e.g., Aas and Kaltenborn, 1995; Ferter et al., 2013; Stensland and Aas, 2014) note, however, that Scandinavian fishers, perhaps Norwegian fishers in particular, do have one distinguishing characteristic: a reputation for consuming more of their catch than do others. Indeed, the retention and consumption rate of the catch in Norway has been high compared to countries like Canada and Scotland where the catch and release (C \& R) rate reaches over 50\% (Thorstad et al., 2008; Ferter et al., 2013; Stensland and Aas, 2014).

Recreational fishing ultimately depends on the status and dynamics of sea trout populations within the ecosystem they habit. Abundance of most salmonids in Norwegian rivers and fjords has shown a long-term decline. Climatic and environmental shifts alter aquatic conditions at all sea trout life stages including coastal species composition, productivity, food webs and interspecific competition in combination with inter individual differences, presumably underpinned by genetically determined reaction norms (Pulido, 2011). During the last 
decades, the abundance of sea trout has declined markedly in many regions (ICES, 2013). The catches in Norwegian rivers have, except for the northernmost areas, declined by $23 \%-70 \%$ during the last two decades (Anon, 2015). It is hypothesized that these declines result from reduced marine survival that is caused at least in part by changes in food supply and/or increased parasite infestations related to fish farming (ICES, 2013; Thorstad et al., 2015). Because sea trout typically are females (e.g., Knutsen et al., 2004; Bordeleau et al., 2018), additional marine mortality has an accentuated potential to negatively affect population recruitment by reducing the egg supply. For instance, the aquaculture farms that are situated close to the marine feeding areas of sea trout might have negative impacts on sea trout growth and survival due to potential sea lice problems (Thorstad et al., 2015; Moore et al., 2018). This negative impact may also affect migration patterns (Halttunen et al., 2017) and choice of migratory strategy of sea trout, and may even threaten sea trout populations and its ecosystems. This may have important implications on ecosystem services in terms of public and private benefits, especially recreational fisheries.

The total river catch of Atlantic salmon and sea trout has fluctuated over time. Although Atlantic salmon has slightly increased in the last few years (Figure 2), sea trout has shown a persistent downward trend. The average catch for the last 10 years is about 350 tons for Atlantic salmon and 48 tons for sea trout, half from northern Norway. The number of sea trout fished are significantly lower, only about $18 \%$ compared to the total of Atlantic salmon fished for the last two decades. The catch portion of sea trout compared to Atlantic salmon has decreased from about $20 \%$ in the early 1990 to $15 \%$ at present. Thus, the specific economic value of this species must be presumed to be lower, as these are similar (anadromous) species and many of the findings from Atlantic salmon fishing should apply. Due to population declines, commercial harvest has gradually closed, and the catch-release programs were introduced and implemented in the late 2000s.

While Norway is home to important stocks of sea trout and Atlantic salmon, it is also the world's largest single producer of farmed Atlantic salmon. The recent decision by the Norwegian government to support the significant expansion of the farming of Atlantic salmon signals the choice to put these salmonids populations at greater risk. Although the level of threat is a hotly debated topic in Norway with a focus on Atlantic salmon rather than on sea trout, there is an increasing recognition that sea trout is also likely to be negatively affected. From 2019, sea trout will also be a part of the new traffic light system that governs decisions about growth in the salmon aquaculture industry (Fiskeridirektoratet, 2018). However, the importance of recreational fishing means that it too must be carefully managed for stocks to thrive: The effort to do so, however, is complicated by the lack of knowledge about this recreational fishery. In addition, there is less basic scientific information about sea trout and how human activity of various kinds affects it (Kallio-Nyberga et al., 2010; Eldøy et al., 2015; Anon, 2018; Blicharska and Rönnbäck, 2018). In the literature that does exist, a common theme is the need for greater basic knowledge about this and similar fisheries (Oh, 2005; Thorstad et al., 2016; Aldvén and Davidsen, 2017).

\section{LITERATURE REVIEW}

\section{Ecosystem System Services}

This paper seeks to increase information about the sea trout by exploring the ecosystem services they deliver to Norwegian society. Ecosystem services are numerous and multidimensional. The Millennium Ecosystem Assessment (Millennium Economic Assessment [MEA], 2003) divides these into four general categories, namely: (a) provisioning ecosystem services (such as food, water, fiber, fuel and other raw-materials and energy sources); (b) cultural ecosystem services (spiritual, aesthetic, recreational and educational benefits, tourism); (c) regulatory ecosystem services (regulation of the climate, water, and natural cycles, biological pump); and finally (d) supporting ecosystem services (maintain services such as nutrition cycling, primary production (Millennium Economic Assessment [MEA], 2003). Broadly speaking, the four categories of services can be merged into two: (i) fundamental services including supporting and regulatory services that maintain ecosystem functioning and resilience, and (ii) demand-derived services including cultural and provisioning services that are derived from human values (Holmlund and Hammer, 1999; TEEB Foundations, 2010). Together these ecosystem services contribute "the basic material needs for a good life, freedom and choice, health, good social relations, and personal security" necessary to human well-being (Millennium Economic Assessment [MEA], 2003).

This article focuses primarily upon the demand-driven cultural ecosystem services provided by sea trout in connection with recreational fishing. Recreational fishing has an economic dimension related to tourism, but as a recreational activity, it contributes to the more intangible aspects of human wellbeing. Human well-being is of recognized importance but it is also extremely broad and difficult to pin down. The difficulty of grappling with the concept of "well-being" is clear from both the work of the MEA and the Norwegian attempt to value Norwegian ecosystem services (Norges Offentlige Utredninger [NOU], 2013). The MEA Framework recognizes five key components of human well-being: the necessary material for a good life, health, good social relations, security and freedom and choice (Millennium Economic Assessment [MEA], 2003). It also identifies seven "Cultural Services" (spiritual and religious, recreational and ecotourism, aesthetic, inspirational, educational, sense of place, cultural heritage) which, along with other services, contribute to human wellbeing of the individual and the community (definition from Millennium Economic Assessment [MEA], 2005; Raymond et al., 2009). They must inevitably be defined in highly contextual and situational ways. Ecosystem services are accordingly a highly normative concept (i.e., value-laden), also called a ‘stakeholder-driven' concept (Millennium Economic Assessment [MEA], 2003; Jax et al., 2013). Such cultural services are particularly difficult to define, operationalize and to measure. 
This underlines the connection between science and society (Liu et al., 2010).

The highly contextual nature of these services is clear in the study of recreational fisheries. A recreational fishery involves a variety of stakeholders, including policy makers, resource users, investors, scientists and the concerned public. These stakeholders differ in their objectives, interests, judgments, values, preferences and perceptions. For instance, stakeholders who directly use or depend on resources and ecosystems (such as fishers) have different objectives and preferences compared to stakeholders who do not directly use them. But even direct users may differ in opinion among themselves as to what aspect of the resource they value. Further, it is increasingly recognized that resources, including those utilized in recreational fishing, exist within in social-ecological systems in which customs, norms and meaning infuse resources with meaning, shape user behavior and accordingly impact the utilization of resources (Hunt et al., 2013; Lynch et al., 2016). What ecosystems services a recreational fishery actually provides and how valuable they are, are likely to vary in the eyes of the various stakeholder observers.

The different assessments of the services provided by a resource such as sea trout will affect end-users' management views, such as what core objectives and strategies of management should be. Understanding how fishers and other stakeholders use the resource and what they actually value with respect to the resources will likely serve to improve management decisions as well as compliance (Oh et al., 2005; Beardmore et al., 2014; Blicharska and Rönnbäck, 2018).

\section{Ecosystem Services and Recreational Fishing}

Sea trout as a fish population and its associate aquatic systems provide a number of fundamental ecosystem services including both supporting and regulating services. Salmonid ecosystems are defined by the long chain of freshwater, estuarine, and marine habitats that individuals in a population must navigate to complete their anadromous life cycles. Like the Atlantic salmon, sea trout may spawn and rear in small headwater streams or larger rivers, and feed for months or years in estuaries or coastal marine waters. The carcasses, eggs, and sperm left behind after spawning deliver a continuous flow of nutrients and energy from the ocean to small coastal streams, rivers, and lakes. Further, predation by terrestrial scavengers and nutrient uptake by riparian vegetation transfers marine-derived nutrients to terrestrial plants and animals.

Here, however, we focus on demand-driven provisioning and cultural services that sea trout have provided to Norwegian society. It today produces valuable food products (fish) harvested for personal use and serves as the basis of recreational fisheries and cultural values, supporting in turn both a locally significant tourism industry and local well-being (Raymond et al., 2009; Kumar, 2010; Norges Offentlige Utredninger [NOU], 2013: 10: citing Kjelden $\mathrm{m}$ fl 2012).

The contribution to human health and well-being of recreational fishing is first and foremost to the health and well-being of the individual fisher. Angling is in general a legendary activity with a passionate following. Izaak Walton's 1653 The Complete Angler was a celebration of angling far before tourism emerged as a serious economic activity and it built on earlier work. British tourists in fact initiated the concept of the recreational angling as well as nature tourism in Norway in the 1860s (Haugen and Vik, 2008; Baklien and Steinset, 2012). While today salmon fishing may get more attention, sea trout fishing has historically generated mythic prose (Bryan, 1977). Today angling for both species is an important activity for foreign tourists and Norwegians alike as well as an ingredient in the Norwegian tourist industry. But what is it that fishing does for the fisher?

Some work on anglers targeting anadromous stocks vary in what they find anglers value in their activity (Bryan, 1977; Fedler and Ditton, 1994; Oh et al., 2005) and there is some evidence regarding the non-monetary value that hosting recreational fishing has for the riparian land owner (Stensland, 2013). What value both anglers and riparian land owners find in the sport or in the resources should affect what kind of management they seek and how much they are willing to pay for it. For example, if the value of fishing is simply being out in nature, then substitutes can be found for angling. A walk in the woods would be an adequate substitute. If fishing or the fish itself are the core services associated with fishing, then substitutions get much harder. On the other hand, if nature is an important part of the fishing experience (that is, both nature and fishing are prized) then fishers might value measures that extend beyond just regulating fish and fishers to protecting habitat.

Another approach is to place recreational fishing in a broader context. Lynch et al. (2016) identified individual, social and environmental aspects of inland fish and fisheries, including recreational fisheries. Hunt et al. (2013) advocated approaching the analysis and management of recreational fishing using Ostrom's (2007) holistic socio-ecological systemic approach which requires, among other things, an understanding of the social significance of the fishery. Morton et al. (2016) examined the political context of recreational and commercial wild Atlantic salmon fisheries of Scotland.

While some work has been done on the importance of fishing for the fishers and on the socio- but especially economic value of Atlantic salmon fishing for selected river owners, little work has been done in advancing understanding the value of the fishing of anadromous stocks for Norwegian society more broadly. This is illustrated by the Norwegian white paper from 2013 that surveyed and evaluated Norwegian ecosystem services and the scientific work done on assessing these (Norges Offentlige Utredninger [NOU], 2013). The presentation of recreational fishing focused most on the economic value of tourism and, while acknowledging the importance of fishing for recreational, health and leisure purposes, had little to say about these and offered no scientific work. "Nature" was in general acknowledged to provide the services of well-being, health, sense of place, spiritual enrichment, religious values, inspiration, knowledge and learning, and the general value of national natural inheritance (naturarv) but very little of this is specific to recreational fishing (Norges Offentlige Utredninger [NOU], 2013). In addition, the sea trout has been present in Norwegian life for millennia, and has presumably also 
been an integral part of the local cultural heritage, its folkways and lore; fishing for sea trout has presumably been a part of the transfer to and development of local ecological knowledge and fishing experience among the young. However, very little work has been done on this social service of trout fishing.

Identifying especially the social-cultural services of recreational fishing rather than trying to measure these services in monetary terms fits with a growing body of literature that investigates the social and personal meaning of recreational fishing as necessary to better management of resources. Again, because anadromous species are generally declining and the aquaculture industry is set to expand dramatically (which may further endanger the stocks), it is important to understand what Norway stands to lose. Informed choices about tradeoffs are only possible if there is adequate knowledge available about anglers' perceptions and concerns.

\section{METHODOLOGY - STRUCTURED SURVEY}

The concept of ecosystem services is anthropocentric as it is based on the benefits provided by ecosystems to society. This is an inherently economic concept and is often treated in terms of economic valuation. Economists commonly employ a total economic value framework (TEV) to capture a wide range of benefits (i.e., values), including intangible benefits, associated with any ecosystem or resource (TEEB Foundations, 2010; Barbier et al., 2011). The value of some provisioning services may be derived from market prices for it or similar goods and some aspects of recreational fishing can be valued by the income it generates. Non-extractive use values, including most socialcultural services related to recreational fishing, however, are not valued by the market because of the absence of relevant markets and poor understanding of its functions and processes (Barbier et al., 2011). They still have value which can be expressed in economic terms, however, based on the preferences that an individual attaches to a good or service given his or her resources. This means in practice they are operationalized as the maximum amount an individual would be willing to pay for a good or a service (even if they are not actually paying for it). A wide variety of values can accordingly be expressed in monetary values (monetarization). Attempts to monetarize the value of recreational fishing is usually done with the intent of understanding how regulation affects the fishery or whether efforts should be made to increase fisheries-related tourism.

Attempts to identify the values produced by recreational fisheries therefore typically employ monetarizing approaches and can include a variety of values or benefits. For instance, Toivonen et al. (2004) examined the economics of recreational fishing, including marine recreational fishing. Olaussen and Skonhoft (2008) conducted a bioeconomic analysis of river fishing for wild Atlantic salmon in Norway. Butler et al. (2009) evaluated the economic impact of recreational fisheries for Atlantic salmon in Scotland. Stensland $(2010,2013)$ looked at the value of fishing rights for Norwegian riparian land owners who traditionally control fishing rights along rivers.
Some of these studies focus primarily on the benefits of this fishing as perceived by direct users - anglers. Blicharska and Rönnbäck (2018) examined the expenditures of anglers who target sea trout in Sweden. Some have used willingness-to-pay (WTP) studies that compare anglers' current expenditures to what they might be willing to pay to keep fishing or fish more, as a way of measuring the value of angling to the angler. For example, Navrud (2001) using the concept of the complete costbenefit analysis, examined the contingent valuation and travel cost to estimate the use value of recreational fishing. Constructed properly, WTP analyses can help identify what aspects of the activity are most valued and also help gauge the depth of commitment for both users and the general public. However, such studies often only hint at what anglers actually value with respect to recreational fisheries for extractive direct-use services.

The more specialized recreational fishing specialization literature uses a variety of approaches including monetarizing and qualitative approaches to identify angler preferences, and this literature has yielded categories of anglers and angler preferences. Bryan (1977), Oh et al. (2005), and Beardmore et al. (2014) and in a more tangential way, Olaussen (2009) identified different values (ecosystem services) and value preferences within the angling community, often differentiating the occasional fisher from the more committed and highly specialized angler. These studies suggested that anglers vary in what they value in the act of fishing with different categories giving different priorities to qualities such as the experience of being out in nature, appreciation for particular settings and specific species of fish, social experiences connected to fishing (connecting with others or being alone), the stress-reducing aspects of fishing, competitive aspects of some fishing, and of course, the pleasure of actually catching and sometimes consuming fish. The idea of such variation in what anglers value is also picked up in the literature examining the increasingly common catch and release practice of freshwater anglers, including anglers in Norway (Ferter et al., 2013). Leisure and health studies approach fishing as an activity of importance to physical, mental and emotional health and this theme is frequently picked up in official documents setting out goals and benefits relating to recreational fisheries. In these studies, the actual catching of fish is usually accorded less importance than are benefits such as spending time in nature, relaxation and the physical activity involved (e.g., McManus et al., 2011; Norges Offentlige Utredninger [NOU], 2013; Griffiths et al., 2017).

This paper adopts a mixed approach to capturing the noneconomic values of recreational fishing for sea trout (and other salmonids) by Norwegian anglers. Building on the findings of the recreational fishing specialization, monetarizing, and leisure and health literatures, a structured questionnaire was developed for Norwegian recreational fishers. Employing a primarily qualitative approach, it asked fishers directly what and how much they value various aspects of their fishing experience (preference for species, fishing areas, retaining catch, enjoyment of fishing trips). It also asked how they perceive the current status of stocks, their opinion of the current management regime and which suggested approaches to management they favor. The monetarization literature led to asking fishers how often 
they fish, how much they spend on fishing, how far they are willing to travel to go fishing, whether they would be willing to pay more for certain fishing licenses as a way of measuring the level of commitment of fishers and what management measures they might prefer.

The survey was first tested with three face-to-face workshops and two rounds of online surveys with invited anglers and land-owners. The final version of the survey is composed of 38 questions including questions relating to anglers' fishing behavior and their views about sea trout population and management, and their socio-demographic information. The questionnaire was administrated using Survey Monkey (a paid online survey software). The survey served multiple purposes.

The final survey was distributed to all members of the NJFF via the NJFF mailing list, with the cooperation of the NJFF. NJFF is a national organization, is the largest interest organization for hunters and anglers in the country and promotes both hunting and fishing for all genders and age groups (NJFF, 2018). This organization is recognized as an important representative of the Norwegian angling community, and is routinely invited to (and does) respond to governmental hearings and draft white papers on topics relating to wild salmonids. NJFF claims around 113 thousand members organized into 573 local chapters all over the country (NJFF, 2018). Reminders to complete the questionnaire were posted on the NJFF Facebook page, also sent to the NJFF mailing list. The questionnaire was also distributed to participants in workshops and symposia organized by the CHASES ${ }^{1}$ project. The data and information from these participants were not included in this analysis.

\section{RESULTS}

\section{Descriptive the Characteristics of Anglers}

We have, so far, received about 100 responses, of which 89 are responses with complete answers and are used for the analysis. Although the sample size seems small compared to the total number of anglers in Norway, it is broadly representative of these anglers and is the only survey to target anglers in general as opposed to those who favor particular rivers. The sample size is large enough to provide useful insights and suggest the direction future work should take, but cannot be considered definitive. It should be noted that ethics approval was not needed in accordance with national guidelines as data were made anonymous. The group profile of respondents to this survey does not match that of the general population of recreational fishers reported by NJFF, although it does resemble the profile of recreational fishers' groups found more generally in the literature (see e.g., Butler et al., 2009). The overwhelming majority of respondents to the survey (98\%) were men. Of these, over $60 \%$ were between the ages of 35-54 (see Table 1).

\footnotetext{
${ }^{1}$ CHASES is a project funded by the Norwegian Research Council to investigate the cconsequences of land-use change and human activity on anadromous salmonids and the ecosystem services that they provide (2016-2020). The detailed information can be found at: https://www.ntnu.edu/museum/the-secret-life- ofsea-trout.
}

TABLE 1 | Summary of social-demographic information of respondents.

\begin{tabular}{|c|c|c|}
\hline Variables & Values & Mean \\
\hline \multirow[t]{5}{*}{ Education } & Secondary school & $3.23 \%$ \\
\hline & High school & $48.39 \%$ \\
\hline & College & $24.19 \%$ \\
\hline & Advanced university & $20.97 \%$ \\
\hline & Others & $3.23 \%$ \\
\hline \multirow[t]{6}{*}{ Household Income } & $<50,000$ Euro & $12.90 \%$ \\
\hline & 50,000 - 75,000 Euro & $27.42 \%$ \\
\hline & $75,000-100,000$ Euro & $25.81 \%$ \\
\hline & 100,000 - 150,000 Euro & 17.74 \\
\hline & Over 150,000 & $4.84 \%$ \\
\hline & Did not answer & $11.29 \%$ \\
\hline \multirow[t]{5}{*}{ Members of organizations } & Fisheries related & $33.90 \%$ \\
\hline & Aquaculture related & $0 \%$ \\
\hline & Environmental related & $6.78 \%$ \\
\hline & No members & $42.37 \%$ \\
\hline & Others & $16.95 \%$ \\
\hline \multirow[t]{7}{*}{ Profession } & State employee & 30.65 \\
\hline & $\begin{array}{l}\text { Service industry (e.g., shops, } \\
\text { hotels, restaurants, banks, etc.) }\end{array}$ & $17.74 \%$ \\
\hline & $\begin{array}{l}\text { Resources (agriculture, forest, } \\
\text { fisheries, aquaculture) }\end{array}$ & $3.22 \%$ \\
\hline & Other industry & $14.52 \%$ \\
\hline & Pensioners & $8.06 \%$ \\
\hline & Unemployed & $6.45 \%$ \\
\hline & Others & $20.97 \%$ \\
\hline \multirow[t]{6}{*}{ Age } & $18-34$ & $25.80 \%$ \\
\hline & $35-44$ & $17.74 \%$ \\
\hline & $45-54$ & $29.03 \%$ \\
\hline & $55-64$ & $30.65 \%$ \\
\hline & $65-74$ & $9.68 \%$ \\
\hline & $75-$ & $4.84 \%$ \\
\hline \multirow[t]{2}{*}{ Gender } & Women & $1.61 \%$ \\
\hline & Men & $98.39 \%$ \\
\hline
\end{tabular}

Respondents came from all around the country, including both heavily urban and rural areas, although the largest single group comes from Trøndelag County, in mid-Norway, which is moderately populated by Norwegian standards (although not by world standards) (SSB, 2018). Trøndelag County is one of the most important areas for Atlantic salmon fishing, although Northern Norway is the most important. The respondents were on the whole better educated than average Norwegians: over $44 \%$ report having a college or university education, compared with about $33.4 \%$ for the country as a whole (SSB, 2018). Most of the respondents were employed and those reporting that they worked in the public sector made up the largest group (30\%). Only 15\% of those who answered were not working ( $7 \%$ were unemployed and $8 \%$ were retired). None of the respondents reported membership in an aquaculture association. On the other hand, only a few (about 7\%) reported membership in an environmental organization. Historically and today, foreign tourists have been important end-users of the salmonid resource, and river-bank owners, who control access 
to rivers have significant income from accommodating both foreign and domestic visitors. However, this paper only focuses on Norwegian anglers, and the questionnaire was not distributed to foreign tourists. The motivations of foreign tourists are accordingly set aside in this article.

Of all respondents, some prefer fjord fishing (56\%) to fishing in the rivers (38\%), which corresponds with the NJFF breakdown $(\sim 60 / 40)$. In our survey, only about $12 \%$ reported fishing for less than 5 years while $64 \%$ of all respondents report that they had been fishing more than 20 times in a variety of settings (rivers and fjords) during 2016. These figures break down into several subgroups. Of all those answering the survey, 37\% prefer fishing Atlantic salmon to sea trout (17\% prefer sea trout), but $41 \%$ have no preference. Of those who take sea trout (either only sea trout or sea trout and other species), the majority (47\%) reported fishing for sea trout for over 20 years, with only $11 \%$ for under 5 years. Those who reported that they only fished sea trout in rivers presented a different profile: in the last 5-10 years on average $46.8 \%$ are causal anglers fishing less than 5 times per year; $34 \%$ are active anglers fishing more than 5 times but less than 20 times, and 19\% are dedicated anglers fishing more than 20 times. Further, about 95\% of these respondents indicate they will go fishing next year. The pool of survey respondents are accordingly in general active and dedicated fishers. This characterization is supported by information about the fishing licenses they hold. Half of anglers have both daily (58\%) and season (44\%) fishing cards. Toivonen et al. (2004) define the frequent fisher as someone who fishes more than 5 times in a given year. Our group reports for the most part being in that category.

\section{Motivations and Ecosystem Services}

What do Norwegian recreational fishers value with respect to fishing? In other words, what motivates them to fish? In the survey, respondents were asked why they fished for sea trout and other salmonids (Atlantic salmon and Arctic char) in particular and what factors most affected their fishing experience. This took the form of asking fishers whether they strongly agreed, agreed, were neutral, disagreed or/and strongly disagreed with two sets of 10 proposed motivations which relate to commonly recognized provisioning and social-cultural ecosystems services.

Figure 3 summarizes the answers from the anglers. First, for many Norwegian fishers eating their catch is an important part of the fishing experience. Nearly $70 \%$ report that they enjoy eating the catch although very few report either retaining or releasing all of their catches, as is discussed below. It should be noted here that fishers were not asked whether they needed to fish in order to feed their families. The response to this suggestion in workshops made it clear that this fishing was recreational and not subsistence, and a question about providing food was dropped from the survey.

This leaves essentially the social-cultural services that this fishery offers, the most difficult to measure. These relate to the social functions fishing can have, the meaning of fishing for individual participants and the role of fishing for the participants' health and welfare (well-being). The five most positively ranked responses relate to the health and welfare

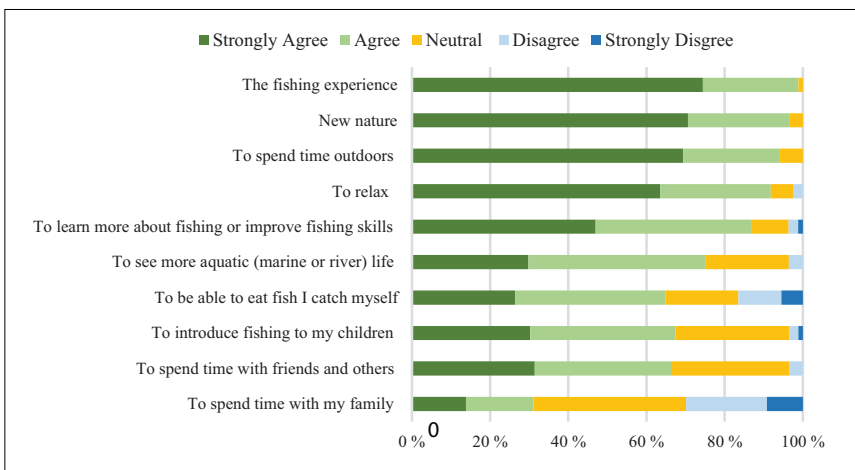

FIGURE 3 | Anglers' motivations to fishing sea trout.

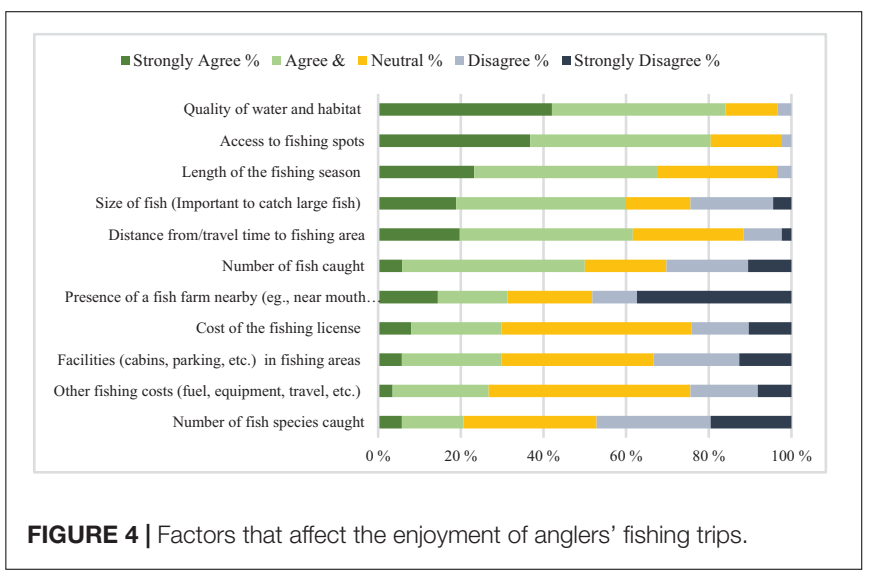

of the individual participants, which are usually categorized as "cultural" services: fishers report that they most valued the fishing experience itself. That is followed by having contact with nature, being outdoors, relaxing, and improving their fishing skills (in all five cases, "agree" and "strongly agree" answers were over $86 \%$ ). These motivations are all rated more highly than is eating the catch.

The questionnaire specifically inquired about social aspects of recreational fishing, focusing on family and social group relationships. The responses indicate that there is a strong social dimension to fishing, but that fishers ranked this as less significant than the personal health and welfare dimension. Sixty-nine percent of respondents "agreed" or "strongly agreed" that they were motivated by the chance to teach their children to fish; about $68 \%$ "agreed" or "strongly agreed" that they valued the chance to spend time with friends. This is roughly the same level of motivation as reported for "eat fish I catch myself." Interestingly, the least popular motivation was in the "social category": "spend time with my family" was the single least popular choice with only just under 32\% "agreeing" or "strongly agreeing," and it was the choice with the greatest number of strongly negative replies: about 30\% "disagreed" or "strongly" disagreed."

A second multi-part question probed what fishers enjoyed about their fishing trip (Figure 4). They indicated that the quality of the water and habitat are more important to the fishing experience than is the number of fish, fish size or even the 


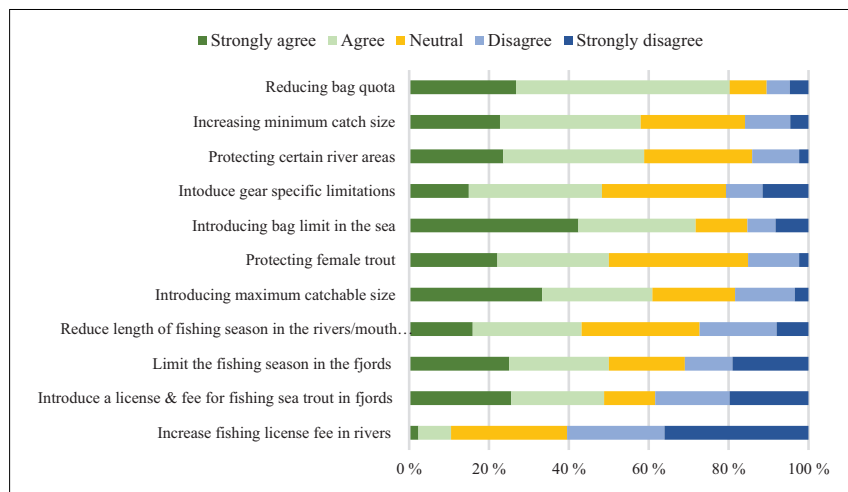

FIGURE 5 | Anglers' view to future fishing regulations and management.

number species of fish caught, even while fishing itself remains an important part of the experience. Access to fishing areas was also an important factor; the cost of fishing (equipment, the cost of the license) and facilities on site (such as cabins) were less important factors.

\section{Attitudes Toward Regulation}

Most of our anglers (64\%) are not satisfied with current management for sea trout fishing while less than one-third (28\%) of the respondents are relatively satisfied. The main reasons leading to such dissatisfaction are 'not the right regulations (34\%)' and 'too few regulations' (29\%). None of the respondents thought that there was too much regulation. They have different opinions, however, as to what the best remedies may be, with respect to regulating sea trout in both coast and rivers environments. The regulation they agree with the most $(80 \%)$ is 'reducing bag limit, followed by 'introducing bag limit in the sea,' 'introducing maximum catchable size,' 'protecting certain river areas' and 'increasing minimum catchable size.' It is worth noting that for these options, less than $20 \%$ of respondents disagreed or strongly disagreed.

The most unwanted regulation - by some margin - is increasing price of the fishing license fee in rivers (Figure 5). This was also the choice that registered the largest number of explicitly negative responses: fully $61 \%$ disagreed or disagreed strongly, with most disagreeing strongly (36\%). More (about 50\%) would accept the introduction of a license and fee in the fjords, however. Their willingness to accept regulations that would affect the core fishing experience (bag limits, size requirements and protecting certain river areas) seems to reflect their acceptance of the need to protect the fish populations as a top priority, while their greater acceptance for paying a fee for fjord fishing than for increasing fees to fish along rivers is more difficult to interpret.

\section{DISCUSSION}

\section{Group Profile and Motivation}

The literature on fishing recognizes that different fishers have different motivations and values. For example, the more casual angler may place a greater premium on catching fish, whereas the more specialized angler may find the fishing experience itself at least as or more important (Bryan, 1977). It is also quite likely that anglers from different areas value recreational fishing differently: for local fishers, fishing may be a part of the fabric of everyday life, and its significance and meaning may vary by locality. For those living in more urban areas, fishing may be an escape from the city and its pressures, a chance to reconnect with their roots, the pursuit of a passion, or all three. Local residents and land owners including non-anglers, may value the ecosystems for clean water and nature enjoyment.

The Norwegian respondents to this survey, as noted, are mostly male, well-educated and committed to fishing. They come from a mix of rural and urban areas. Given the long-standing conflict of interest between aquaculture interests and those who fish for salmonids, it is at least interesting that none of the respondents report working in the aquaculture sector. More respondents report fishing in fjords than in rivers. This may be because fishing in the fjord is free, while fishing in rivers typically requires the payment of a license fee to access, and have temporal and spatial restrictions.

Judging by responses here, for these fishers salmonid fishing is about, first, personal enjoyment and fulfillment. Fishers rank the" fishing experience" most highly and "learn more about fishing and improve fishing skills" fairly highly. The Norwegians that answered this survey enjoy being out in nature, and learning more about it. "Relaxation" scored very high as an important benefit of fishing. "Relaxation" is an important aspect of the concept of "recreation," and both are associated with health benefits. Clearly, for those answering the survey, just fishing in river for a couple of hours provided inspiration, aesthetic enjoyment and the pleasure of being out in nature and interacting with wild life. While "recreational" fishing is frequently discussed as beneficial and health benefits are frequently assumed, little work has been done to quantify just what and how large these benefits might be (Griffiths et al., 2017). Given the pressures of today's society, the recreational benefits of fishing, including the relaxation aspect, should not be casually dismissed.

Respondents also value the fish themselves, although they rank other aspects of fishing above how many fish or how many fish species they catch (the length of the fishing season is a more important factor). While $70 \%$ do report that they enjoy eating fish they catch themselves, the fairly high educational level of the respondents suggests that the "food" aspect (a provisioning service) is less important than is the "caught myself" element (a cultural service). In pure monetary terms, the money anglers spend on fishing trips would buy a good deal more trout in the stores (see below).

And yet, Norwegians do have a tendency to consume more of their catch than do others, as noted above. This is important because catch and release angling is increasing around the world and may come to play an important role (as a regulation or a norm) in salmonid management. The Norwegian tendency may be a legacy of the country's traditional harvest-oriented culture for fishing and hunting (e.g., Aas and Kaltenborn, 1995). However, this seems to be changing (Stensland and Aas, 2014). The aggregate release rate for both Atlantic salmon and sea 
trout has increased in Norway from about 5\% in 2009 to $20 \%$ in 2017. In 2012, a national survey found for the first time that more Norwegians supported the idea than opposed it (Stensland et al., 2013). In the survey discussed here, only $2 \%$ of respondents reported that they keep all of their catch, and $8 \%$ reported releasing all of their catch. The great majority report that they do some mix of both, but with a trend in favor of C \& R: 67\% keep some fish and 23\% keep most of their catch. These results seem to agree with the most recent (2017) national statistics (80\% keeping vs. 20\% releasing for both Atlantic salmon and sea trout).

Still important, but less important than expected, are the social aspects: significantly fewer "agree strongly" that they are motivated to fish because of the time spent with family. With less than half answering that they agreed strongly or agreed with the proposition that they enjoyed fishing as a way of spending time with their family, fishing does not seem to play much of a role in with respect to social rituals relating to family life. Ironically, it could play a therapeutic role in family life by allowing men to relax away from home as $98 \%$ of anglers who responded to the survey are men.

That being said, while our respondents were not keen on fishing as a way of spending time with their family per se, nearly $70 \%$ strongly agreed or agreed with the motivation of introducing fishing to their children. Teaching one's children to fish can have positive impact on family bonds (a social function) but it can also have the important function of transferring knowledge across generations, serving to preserve both knowledge of local resources and conditions and cultural practice. The interaction between parents (perhaps here, "fathers" is appropriate) and children in the use of natural resources is widely recognized to be an important part of the preservation of local ecological knowledge (Lynch et al., 2016). Local ecological knowledge is increasingly recognized as important for adding to baseline knowledge especially when good historical data is missing (Bailey et al., 2016). In this connection it is interesting to note that the Scientific Council for Salmonid Management (Anon, 2015) recognizes the knowledge of the resources users and actively solicits local knowledge on takes of salmonids. It is also worth noting that local interest in fishing can have additional, underappreciated benefits: local residents and anglers assisted the researchers of CHASES project in the placement of monitoring stations and in the tasks of tagging fish. Local fishing enthusiasts have also warned researchers when monitoring equipment was disturbed. Local residents exhibited a pride of place and of their fishery (as a livelihood and/or life style); they turned out for meeting to learn more and to provide assistance. The supposed gap between scientists and "most people" was affectively bridged (Bailey et al., 2016).

Scientists are usually most interested in local knowledge about species and their habitat, but local knowledge can consist of much more. Recreational fisheries, like commercial fisheries, exist not just within aquatic ecosystems but within socio-economic systems (Hunt et al., 2013). Fishing is a part of a locality's and a country's social life, cultural heritage, folkways and lore and fishers navigate and recreate these (or not) these when they fish. As the survey indicated through the question on travel time, much recreational fishing is fairly local. This may mean that fishing is an activity of social and also cultural importance to specific communities. The questions asked in this survey do not allow us to pursue such questions here. Future work should do more to uncover the meaning of fishing for specific rural communities.

In addition, nearly $70 \%$ reported that they valued fishing as a way of spending time with friends. Social interaction can also help preserve and transfer local ecological knowledge. But it has further benefits. Fishing with friends can build social capital by increasing the number of their social connections and strengthening bonds (Floress et al., 2011). Although not measured directly by this survey, fishing also encourages membership in the socially and politically active organizations dedicated to maintaining the sport and its required habitat, such as the NJFF that hosted this study or the organization Norwegian Salmon Rivers (NSR). Membership in such organizations are both a result and a cause of this fishing, and the NJFF and NSR are important elements of the highly organized Norwegian society. In addition, both organizations work to preserve the wild stocks of anadromous fish as an active participants in the relevant hearings by which Norwegian governments set policy.

As mentioned earlier, expenditure on fishing trips can be used as one indicator of the value of ecosystem services related to recreational fishing. But the social-cultural services of recreational fishing are much larger than the fishing expenditure and quantitatively measuring such social-cultural services has been proven difficult, if not impossible. Such qualitative measurement can provide understanding and insight about the importance of ecosystem services and equally be used in future management in order to combine fish, fisheries and ecosystem in a complete model. Our findings suggest that the benefits fishers get from fishing are not easily replaced by other outdoor activities. Much of their enjoyment is linked specifically to the activity of fishing.

\section{Attitudes Toward Management}

When resources are under pressure, attitudes toward regulation become especially important. It is also possible that fishers will be more willing to accept more stringent management measures in such a situation. As noted above, stocks of sea trout are in decline, and Atlantic salmon have fluctuated, although they have been slightly better of late. Over $50 \%$ of the respondents stated that they expected the stock of sea trout to decline over the next 10 years. Given the evidence and perceptions that these stocks are declining, what might fishers be willing to do to preserve them?

The first question might be, just how important is fishing to these fishers? The number of fishing trips that respondents report taking per year and the motivations that drive them suggest that the respondents are committed fishers. How committed to fishing and maintaining the stocks are they? Since recreational fishing has been one of their leisure activities, anglers' expenditure on fishing can be used as an indicator of their commitment to the activity. The survey respondents report an average of spending (preliminary) 18500 NOK (roughly 2200 USD) in year 2016 for the whole family on recreational fishing for 
anadromous species in both fjords and rivers. This supports the assumption that the respondents are fairly committed fishers, in line with other studies that suggest that Norwegians are among the most avid anglers in the world as measured by their participation in fishing per capita and by spending (Hyder et al., 2018). These figures suggest that anglers may be committed enough to consider fairly stringent regulations that might preserve the stocks. Indeed, fishers have already had to accept progressively restrictive regulations, although these vary from river to river, and from season to season. Management has been playing a big role in regulating sea trout populations and fishing activities.

The responses to this survey indicate that the respondents are willing to accept more regulation, such as lower catch limits on rivers, the introduction of catch limits on the fjords, and regulations regarding catch size. As noted, C \& R already seems to be on the increase. There may be many different motivations for engaging in C \& R, however, including local rules and personal motivations (such as selecting for size or a desire to protect the resource). It is difficult to interpret the greater significance of these results. However, it is worth noting that $57 \%$ respondents believe that the sea trout population has been declining in the last 10 years while only $17 \%$ think it is increasing. There can be geographical differences since the majority respondents are from mid-Norway where wild stocks are under more pressure compared to Northern and Southern Norway where there is no or slight decline in reported catches. Many of the fishers who answered this study fish fairly locally: $42 \%$ usually traveled 30 min or less to go fishing and many are from Trøndelag. This supports the idea that there is a connection between the increased willingness of Norwegian anglers to release some of their catch and the decline in Norwegian stocks (Stensland and Aas, 2014).

Fishers are quite clear, however, that they do not want to pay more for a license to catch fish in river. This finding merits more research. It is possible that the reluctance to pay fees or higher fees is related to traditional Norwegian attitudes about freedom of access to common pool resources (fjord fishing) (Borch, 2009) or attitudes toward paying riverbank owners more (angling in rivers). It is also possible that there is greater acceptance for further regulation of sea fishing.

\section{CONCLUSION}

This paper has taken an ecological services approach to understanding the importance of sea trout and similar species in Norway. As an anadromous species, the sea trout is one of keystone species of Norway's watershed aquatic ecosystems and plays an important role in both freshwater and marine systems. But this paper has focused on social-cultural services. The provisioning service performed by sea trout is relatively easy to identify and understand, but it is not the most important service in this context. Norwegians like their wild-caught fish, but it is also clear that eating the fish is a part of a larger package of experiences associated with fishing activities.
The difficulty has always been to identify what that larger package of key experiences is and understand just what services and how valuable they are. Recreational fishing is a multifaceted activity with complex benefits for individuals and society. This study suggests that the most important part of the fishing experience is at the individual level. Norwegians enjoy and find relaxation in the act of fishing. Enjoyment of nature and relaxation are broadly recognized to be important aspects of human well-being. But while fishers enjoy nature, it is not nature in the abstract: it is nature related to the fishing experience. From this perspective, fishing cannot be replaced by a walk in the woods. Fishing is also an important social experience. Interactions between fathers and children and social interactions among fishers and their friends can maintain and build local ecological knowledge as well as build and strengthen social networks. This survey did not pursue this, but this is a line of inquiry that should be explored in more depth.

Human well-being and social functions are important cultural services. They are difficult to quantify in monetary terms, but they are potentially far more valuable in this context than the value of the fish consumed. If a sea trout population were to be lost, these services attached to recreational fishing can well be lost with them. This will result in large impacts on people's life and society as they will lose access to recreational activity that provides various social-cultural services supporting local wellbeing. From a long term perspective and society at large, what would be expected if a salmonids species (including sea trout and Atlantic salmon) were to disappear? What other species would fill that niche? Besides the loss of salmonids, would the ecosystem change its nature in some way that we humans would notice or be affected by?

Finally, the value that fishers place on being in nature and in the quality of the water and habitat suggests that sea trout (and salmonid fishing in general) can produce important benefits for society. By strengthening social-ecological connections to sea trout, stakeholders and policy makers become more aware of interdependency between fish populations, ecosystem services and human societies, and develop appropriate management actions and policies to adopt such migratory strategies (Kooiman and Jentoft, 2009). It is not just that the stocks should be maintained for the benefit of fishers; fishing should be maintained as a way of preserving the stocks as Thorstad et al. (2008) suggest was the case in Maine when angling was once again allowed.

This survey suggests that recreational fishers recognize that salmonid stocks are struggling and that they are willing to accept greater restrictions. Norwegian anglers have already accepted limits on catches and payments of license fees and their increased willingness to release a part of their catch may suggest a commitment to preservation of the stocks. Increasing license fees for river fishing, however, does not seem like a strategy that will pay off over the longer term. The situation of anadromous stocks, especially sea trout, is growing precarious, and Norwegian management authorities have a legal responsibility to maintain them. Fishers are both the consumers of management as well as practitioners: more attention needs to be paid to what fishers value, the assessments they make, the regulations they think may be useful and the regulations they are likely to both accept and 
obey. Having different objectives and preferences will likely mean that anglers and other stakeholders will respond differently to management measures: better understanding of the meaning of trout fishing may help improve management and its legitimacy (Bryan, 1977; Fedler and Ditton, 1994; Hunt et al., 2013).

\section{AUTHOR CONTRIBUTIONS}

YL designed and conducted the research, analyzed the data, and wrote the manuscript. JB analyzed the data and wrote the manuscript. JD designed and wrote the manuscript.

\section{REFERENCES}

Aas, O., and Kaltenborn, B. P. (1995). Consumptive orientation of anglers in Engerdal, Norway. Environ. Manage. 19, 751-761. doi: 10.1007/BF0247 1957

Aldvén, D., and Davidsen, J. G. (2017). "Marine migrations of sea trout (Salmo trutta). sea trout: science \& management," in Proceedings of the 2nd International Sea Trout Symposium, ed. G. Harris (Dundalk).

Anon (1995). Lov om Laksefisk og Innlandsfisk mv. (Lakse-og Innlandsfiskloven). Available at: https://lovdata.no/dokument/NL/lov/1992-05-15-47 (accessed May 15, 1992).

Anon (2015). Vedleggsrapport Med Vurdering av Måloppnåelse for de Enkelte Bestandene. Rapport fra Vitenskapelig råd for lakseforvaltning nr 8b, $785 \mathrm{~s}$.

Anon (2018). Status for Norske Laksebestander i 2018. Rapport fra Vitenskapelig råd for lakseforvaltning nr $11.126 \mathrm{~s}$.

Bailey, J., Liu, Y., and Davidsen, J. G. (2016). Bridging the gap between fisheries science and society: exploring fisheries science as a social activity. ICES J. Mar. Sci. 74, 598-611. doi: 10.1093/icesjms/fsw203

Baklien, A. T., and Steinset, T. A. (2012). Fritidsfiske etter laksefisk: Når villaksen bit i norske elver. Statistisk sentral byrå. Available at: https://www.ssb.no/jord-skog-jakt-og-fiskeri/artikler-og-publikasjoner/ naar-villaksen-bit-i-norske-elvar (accessed March 25, 2019).

Barbier, E. B., Hacker, S. D., Kennedy, C., Koch, E. W., Stier, A. C., and Silliman, B. R. (2011). The value of estuarine and coastal ecosystem services. Ecol. Monogr. 81, 169-193. doi: 10.1890/10-1510.1

Beardmore, B., Hunt, L. M., Haider, W., Dorow, M., and Arlinghaus, R. (2014). Effectively managing angler satisfaction in recreational fisheries requires understanding the fish species and the anglers. Can. J. Fish Aquat. Sci. 72, 500-513. doi: 10.1139/cjfas-2014-0177

Blicharska, M., and Rönnbäck, P. (2018). Recreational fishing for sea troutResource for whom and to what value? Fish Res. 204, 380-389. doi: 10.1016/ j.fishres.2018.03.004

Borch, T. (2009). Contested coastal commercialization: marine fishing tourism in norway. Mast 8, 33-51.

Bordeleau, X., Davidsen, J. G., Eldøy, S. H., Sjursen, A. D., Whoriskey, F. G., and Crossin, G. T. (2018). Nutritional correlates of spatio-temporal variations in the marine habitat use of brown trout, salmo trutta, veteran migrants. Can. J. Fish. Aquat. Sci. 75, 1744-1754. doi: 10.1139/cjfas-2017-0350

Bryan, H. (1977). Leisure value systems and recreational specialization: the case of trout fishermen. J. Leis. Res. 9, 174-187. doi: 10.1080/00222216.1977.119 70328

Butler, J. R., Radford, A., Riddington, G., and Laughton, R. (2009). Evaluating an ecosystem service provided by Atlantic salmon, sea trout and other fish species in the River Spey, Scotland: the economic impact of recreational rod fisheries. Fish. Res. 96, 259-266. doi: 10.1016/j.fishres.2008.12.006

Eldøy, S. H., Davidsen, J. G., Thorstad, E. B., Whoriskey, F., Aarestrup, K., Næsje, T. F., et al. (2015). Marine migration and habitat use of anadromous brown trout (Salmo trutta). Can. J. Fish. Aquat. Sci. 72, 1366-1378. doi: 10.1139/cjfas2014-0560

Fedler, A. J., and Ditton, R. B. (1994). Understanding angler motivation in fisheries management. Fisheries 19, 6-13. doi: 10.1577/1548-8446(1994) 019<0006:UAMIFM>2.0.CO;2

\section{FUNDING}

This manuscript is funded by the Norwegian Research Council through the project CHASES (project number 255110).

\section{ACKNOWLEDGMENTS}

Our thanks go to all the anglers who have participated in our workshops and responded our survey, and special thanks goes to Steinar Paulsen from the NJFF for the suggestions with early version of the survey and support with the survey distribution.

Fiskeridirektoratet (2018). Produksjonsområder. Available at: https://www. fiskeridir.no/Akvakultur/Tildeling-og-tillatelser/Kapasitetsoekning-2017-2018/ Produksjonsomraader (accessed August 16, 2018).

Ferter, K., Weltersbach, M. S., Strehlow, H. V., Vølstad, J. H., Alós, J., Arlinghaus, R., et al. (2013). Unexpectedly high catch-and-release rates in European marine recreational fisheries: implications for science and management. ICES J. Mar. Sci. 70, 1319-1329. doi: 10.1093/icesjms/fst104

Floress, K., Prokopy, L. S., and Allred, S. B. (2011). It's who you know: social capital, social networks, and watershed groups. Soc. Nat. Res. 24, 871-886. doi: 10.1080/08941920903493926

Griffiths, S. P., Bryant, J., Raymond, H. F., and Newcomb, P. A. (2017). Quantifying subjective human dimensions of recreational fishing: does good health come to those who bait? Fish Fish. 18, 171-184. doi: 10.1111/faf.12149

Halttunen, E., Gjelland, K. Ø, Hamel, S., Serra-Llinares, R. M., Nilsen, R., Arechavala-Lopez, P., et al. (2017). Sea trout adapt their migratory behaviour in response to high salmon lice concentrations. J. Fish Dis. 41, 953-967. doi: $10.1111 /$ jfd. 12749

Haugen, M. S., and Vik, J. (2008). Farmers as entrepreneurs: the case of farm-based tourism. Entrep. Small Bus. 6, 321-336. doi: 10.1504/IJESB.2008.019130

Holmlund, C. M., and Hammer, M. (1999). Ecosystem services generated by fish populations. Ecol. Econ. 29, 253-268. doi: 10.1016/S0921-8009(99)00015-4

Hunt, L. M., Sutton, S. G., and Aringhaus, R. (2013). Illustrating the critical role of human dimensions research for understanding and managing recreational fisheries within a social-ecological system framework. Fish. Manage. Ecol. 20, 111-124. doi: 10.1111/j.1365-2400.2012.00870.x

Hyder, K., Weltersbach, M. S., Armstrong, M., Ferter, K., Townhill, B., Ahvonen, A., et al. (2018). Recreational sea fishing in Europe in a global context-Participation rates, fishing effort, expenditure, and implications for monitoring and assessment. Fish Fish. 19, 225-243. doi: 10.1111/faf.12251

ICES (2013). Report of the Workshop on Sea Trout (WKTRUTTA). Copenhagen: ICES Headquarters, 280.

Jax, K., Barton, D. N., Chan, K. M., de Groot, R., Doyle, U., Eser, U., et al. (2013). Ecosystem services and ethics. Ecol. Econ. 93, 260-268. doi: 10.1016/j.ecolecon. 2013.06.008

Kallio-Nyberga, I., Jutila, E., Koljonenb, M. L., Koskiniemic, J., and Saloniemid, I. (2010). Can the lost migratory Salmo trutta stocks be compensated with resident trout stocks in coastal rivers? Fish. Res. 102, 69-79. doi: 10.1016/j. fishres.2009.10.011

Knutsen, J. A., Knutsen, H., Olsen, E. M., and Jonsson, B. (2004). Marine feeding of anadromous Salmo trutta during winter. J. Fish Biol. 64, 89-99. doi: 10.1111/ j.1095-8649.2004.00285.x

Kooiman, J., and Jentoft, S. (2009). Meta-governance: values, norms and principles, and the making of hard choices. Public Adm. 87, 818-836. doi: 10.1111/j.14679299.2009.01780.x

Kumar, P. (ed.). (2010). The Economics of Ecosystems and Biodiversity: Ecological and Economic Foundations. London: Earthscan.

Liu, S., Costanza, R., Farber, S., and Troy, A. (2010). Valuing ecosystem services: theory, practice and the need for a trans-disciplinary synthesis ecological economics reviews. Ann. N. Y. Acad. Sci. 1185, 54-78. doi: 10.1111/j.1749-6632. 2009.05167.x

Liu, Y., Olaussen, J. O., and Skonhoft, A. (2011). Wild and farmed salmon in Norway-a review. Mar. Policy 35, 413-418. doi: 10.1016/j.marpol.2010.11.007 
Lynch, A. J., Cooke, S. J., Deines, A. M., Bower, S. D., Bunnell, D. B., Cowx, I. G., et al. (2016). The social, economic, and environmental importance of inland fish and fisheries. Environ. Rev. 24, 115-121. doi: 10.1139/er-2015-0064

McManus, A., Newton, W., Storey, J., and White, J. (2011). Identifying the Health and Well-Being Benefits of Recreational Fishing. Report No: 17122011. Perth: Curtin University.

Millennium Economic Assessment [MEA] (2003). Ecosystmes and Human WellBeing: A Framework for Assessment. Washington, DC: Island Press.

Millennium Economic Assessment [MEA] (2005). Millennium Ecosystem Assessment. Ecosystems and Human Well-Being: Biodiversity Synthesis. Washington, DC: World Resources Institute.

Moore, I., Dodd, J. A., Newton, M., Bean, C. W., Lindsay, I., Jarosz, P., et al. (2018). The influence of aquaculture unit proximity on the pattern of Lepeophtheirus salmonis infection of anadromous Salmo trutta populations on the Isle of Skye. Scotland. J. Fish Biol. 92, 1849-1865. doi: 10.1111/jfb.13625

Morton, J., Ariza, E., Halliday, M., and Pita, C. (2016). Valuing the wild salmon fisheries of Scotland: the social and political dimensions of management. Mar. Policy 73, 35-45. doi: 10.1016/j.marpol.2016.07.010

Navrud, S. (2001). Economic valuation of inland recreational fisheries: empirical studies and their policy use in Norway. Fish. Manage. Ecol. 8, 369-382. doi: 10.1046/j.1365-2400.2001.00267.x

NEA (2018). Laksefisket I Norge. Trondheim: Miljødirektoratet.

NJFF (2018). Norges Jeger- og Fiskerforbund. Available at: https://www.njff.no/ Organisasjon/Sider/om-njff.aspx (accessed June 25, 2018).

NMA (2018). Laksen Skaper Inntekter, Naturopplevelser og Friluftsliv, og Den er et Grunnlag for å Ivareta Tradisjoner og Kultur. Available at: http://www.miljodi rektoratet.no/no/Tema/Arter-og-naturtyper/Villaksportalen/Laksefiske-iNorge/ (accessed June 26, 2018).

Norges Offentlige Utredninger [NOU] (1999). You Can't Please Everyone? (Til laks åt alle kan ingen gjera. Available at: https://www.regjeringen.no/no/ dokumenter/nou-1999-09/id141590/ (accessed July 18, 2018).

Norges Offentlige Utredninger [NOU] (2013). Nature's Goods: On the Values of Ecosystem Services (Naturens Goder: Om Verdier av Økosystemtjenester). Available at: https://www.regjeringen.no/no/dokumenter/nou-2013-10/id734440/ (accessed October 28, 2011).

Oh, C.-O. (2005). Understanding recreationists' attitudes toward and preferences for natural resources conservation. Doctoral dissertation, Texas A\&M University. Texas A\&M University. Available at: http://hdl.handle.net/1969.1/2632

Oh, C.-O., Ditton, R. B., Gentner, B., and Riechers, R. (2005). A stated preference choice approach to understanding angler preferences for management options. Human Dimensions of Wildlife 10, 173-186. doi: 10.1080/10871200591003427

Olaussen, J. O. (2009). Bandwagon or snob anglers? Evidence from Atlantic salmon recreational fishing. Marine Resource Economics 24, 387-403. doi: 10.1086/mre. 24.4.42629663

Olaussen, J. O., and Skonhoft, A. (2008). A bioeconomic analysis of a wild Atlantic salmon (Salmo salar) recreational fishery. Marine Resource Economics 23, 273-293.

Ostrom's, E. (2007). A diagnostics approach for going beyond panaceas. PNAS 104, 15181-15187. doi: 10.1073/pnas.0702288104
Pulido, F. (2011). Evolutionary genetics of partial migration - the threshold model of migration revis(it)ed. Oikos 120, 1776-1783. doi: 10.1111/j.1600-0706.2011. 19844.x

Raymond, C. M., Bryan, B. A., MacDonald, D. H., Cast, A., Strathearn, S., Grandgirard, A., et al. (2009). Mapping community values for natural capital and ecosystem services. Ecol. Econ. 68, 1301-1315. doi: 10.1016/j.ecolecon.2008.12.006

SSB (2018). Elvefiske etter laks, sjøaure og sjørøye. Available at: https://www.ssb.no/ jord-skog-jakt-og-fiskeri/statistikker/elvefiske (accessed December 13, 2018).

Stensland, S. (2010). Fishing rights and supply of salmon angling tourism in mid-Norway. Scand. J. Hosp. Tour. 10, 207-230. doi: 10.1080/15022250.2010. 495483

Stensland, S. (2013). Landowner's perception of risk sources and risk management strategies in norwegian salmon angling tourism. Scand. J. Hosp. Tour. 13, 208-227. doi: 10.1080/15022250.2013.830362

Stensland, S., and Aas, $\varnothing$ (2014). The role of social norms and informal sanctions in catch-and-release angling. Fish. Manage. Ecol. 21, 288-298. doi: 10.1111/fme. 12078

Stensland, S., Aas, Ø., and Mehmetoglu, M. (2013). The influence of norms and consequences on voluntary catch and release angling behavior. Hum. Dimens. Wildl. 18, 373-385. doi: 10.1080/10871209.2013.811617

TEEB Foundations (2010). The Economics of Ecosystems and Biodiversity: Ecological and Economic Foundations. Washington, DC: Earthscan.

Thorstad, E. B., Næsje, T. F., Mawle, G. W., and Plicansky, D. (2008). “The Atlantic Salmon C \& R Story, pp. 219-222 in the chapter "trends in catch and release" edited by David Policansky, which was in turn page 202-236," in Global Challenges in Recreational Fisheries, eds Ø. Aas, R. Arliinghaus, R. B. Ditton, D. Policansky, and H. L. Schramm (Hoboken, NJ: Blackwell Publishing).

Thorstad, E. B., Todd, C. D., Uglem, I., Bjørn, P. A., Gargan, P. G., Vollset, K. W., et al. (2015). Effects of salmon lice Lepeophtheirus salmonis on wild sea trout Salmo trutta-a literature review. Aquac. Environ. Interact. 7, 91-113. doi: 10.3354/aei00142

Thorstad, E. B., Todd, C. D., Uglem, I., Bjorn, P. A., Gargan, P. G., Vollset, K. W., et al. (2016). Marine life of the sea trout. Mar. Biol. 163:47. doi: 10.1007/s00227016-2820-3

Toivonen, A.-L., Roth, E., Navrud, S., Gudbergsson, G., Appelblad, H., Bengtsson, B., et al. (2004). The economic value of recreational fisheries in Nordic countries. Fish. Manag. Ecol. 11, 1-14. doi: 10.1046/j.1365-2400.2003. 00376.x

Conflict of Interest Statement: The authors declare that the research was conducted in the absence of any commercial or financial relationships that could be construed as a potential conflict of interest.

Copyright (c) 2019 Liu, Bailey and Davidsen. This is an open-access article distributed under the terms of the Creative Commons Attribution License (CC BY). The use, distribution or reproduction in other forums is permitted, provided the original author(s) and the copyright owner(s) are credited and that the original publication in this journal is cited, in accordance with accepted academic practice. No use, distribution or reproduction is permitted which does not comply with these terms. 